\title{
THE IMPAGT OF GEOPOLITICAL RISKS ON TOURISM
}

\author{
Marius-Cristian Neacşu ${ }^{1 *}$, Silviu Negut $t^{2}$ and Gheorghe Vlăsceanu ${ }^{3}$ \\ ${ }^{1223)}$ The Bucharest University of Economic Studies, Romania
}

\section{Please cite this article as:}

Neacşu, M. C., Neguț, S. and Vlăsceanu, G., 2018. The Impact of Geopolitical Risks on Tourism. Amfiteatru Economic, 20(Special no. 12), pp. 870-884.

\section{Article History}

Received: 6 August 2018

Revised: 7 September 2018

Accepted: 7 October 2018

DOI: $10.24818 / \mathrm{EA} / 2018 / \mathrm{S} 12 / 870$

\begin{abstract}
This study captures the new context of contemporary tourism activity developing within the emergence of geopolitical risks. Tourism, an expression of freedom, has become more and more conditioned by geopolitics, thus by power manifestation in the sense of freedom being limited. Therefore, this study is an exploratory analysis meant to identify the impact of geopolitical risks on tourism activities.
\end{abstract}

Keywords: geopolitics, geopolitical risks, global terrorism, tourism.

JEL Classification: L83, F51, Z32.

\section{Introduction}

Context. Living in a "geopolitical world" and in a "geopolitical society" (Munoz, 2013, p. 4) is no longer a novelty, the emergence of geopolitical risks being an obvious aspect in recent years.

Although Fukuyama's "pax liberalis" from the new global order, at the end of the Cold War, in the form of the "world liberal revolution" (Fukuyama, 1997, p. 66), has not yet been instated, besides, the rule-based multilateral world sinks steeply towards illiberalism, and the emergence of a new form of authoritarian state, at present, it is enough to select only a few from so many events in recent years, to illustrate the dominance of geopolitics: the Arab Spring (2011-present); the conflict in Syria (2011-present); Euro-Maidan, (re)annexation of the Crimean Peninsula by Russia, frozen conflict and the New Russia in eastern Ukraine (2014-present); ,the ghost state” of Syraq (2015-2017) and ISIS, terrorist attacks in Brussels, Paris, (2015-2018) etc. And these are only a few, but there is a common feature: while the event is local or regional, the impact is global. For example, some local incidents in Tunisia in the spring of 2011 triggered the "Arab Spring" phenomenon, which spread across North Africa and the Near and Middle East, with the high tensioned reached in Syria, where civil

\footnotetext{
*Corresponding author, Marius-Cristian Neacşu - marius.neacsu@ase.ro
} 
war triggered an international conflict involving the great powers (US, Russia), with the deployment of a global terrorist organization that for the first time had a specific territory (the so-called „Syraq”, with no border between Syria and Iraq), all of which triggered an atypical migratory flow of "economic refugees" (Neacşu, 2016, p. 15) in Europe, which triggered a systemic crisis within the European Union, culminating with the ongoing Brexit and global divergences between Europe and the US, etc.

As a result, the geopolitical risk has started being recognized as a global risk, with significant effects in several economic areas (finance, trade, business, tourism etc.). For example, Pierre Fournier, the "new geopolitical analyst" of the prestigious Canadian Institution La Financière Banque Nationale, explains the importance of understanding this type of risk: "The Economic science and its entire mathematical formula system are no longer enough to explain all the bumps shaping our planet" (Normand, 2009).

Since then, the geopolitical risk has become a common reports syntax for the large transnational companies of various international institutions and bodies. For example, with regards to the types of risks that could affect the international business environment for 2018, all these reports (AON, Bank of England, Boston Division of International Finance, Eurasia Group, Gallup, World Economic Forum, World Bank, Institute for Economics and Peace, Stratfor, Zurich Insurance Group etc.) identify the geopolitical risks as the most profound, the most heavily perceived.

Within this context, on the background shaped by the complex relationship between geopolitics and economy and the intensification of interdependencies and reciprocal conditions, it becomes obvious that tourism as an economic activity and a social phenomenon (from 2012, a flow of over one billion international tourists moves on the surface of the Globe every year, cf. World Bank, 2018), is affected by geopolitical events. If geopolitics is the expression of the act of power (Neguţ, 2008), tourism is the expression of freedom, which tends to be increasingly conditioned by these power games (Neguţ and Neacşu, 2013).

The purpose of this study derives from the previously mentioned context, namely identifying the impact that geopolitical risks have on tourism activity. A series of questions further arise: to what extent do geopolitical events affect the tourism activity? In what dimensions? What are the most impacted elements? Globally, the number of international tourists has grown each year, despite the rise in geopolitical risks. Then, where should we be looking for the effects of the phenomenon from a territorial distribution perspective?

The innovation of this study also derives from its purpose: so far, tourism and geopolitics were two areas that you could've hardly been associated. The reality of the present is, however, attesting to this contradictory existence: when war or when terrorist attacks are concerned, the tourist phenomenon is affected, in the most unpredictable ways, from the disappearance of landmarks, wiped off the face of the earth (such as Palmira in Syria, on UNESCO World Heritage List, dynamited by ISIS in 2017) up to quantitative and also qualitative changes in tourism flows.

The novelty of this research is also striking: from economy, back to geopolitics. From liberalism and economic globalization without boundaries, to the restart of the construction of walls and fences, to authoritarian states, to presidents for life, the emergence of nuclear conflict and global terrorism. The manifestation of hard power, (i.e. geopolitics), and freedom conditioned by power games, (i.e. tourism), are forced to co-operate in this turbulent world. 
With regards to the methodology used, this consisted of a series of qualitative and quantitative analyses, the results of which prove the effects of the geopolitics on tourism activity.

Moreover, the applicative value of research has two dimensions: a theoretical one, the geopolitical risk being a new type of risk that needs to be anticipated and managed, with an increasingly powerful role in decision-making processes - it's worth noticing how many schools (bachelor, master, doctorate) have developed over time serving this purpose - and an applicative dimension: the designing of tourist packages (either on self-service regime or through travel agencies), travel insurance, tourism policies and business etc. will be reconfigured according to this conditioning.

The present study is structured according to scientific standards, starting with an explanatory and justifying introduction to the context in which the research was carried out, followed by a critical analysis of the specialized literature, a synthetic presentation of the research methodology and the results obtained, followed by conclusions and bibliography.

\section{Review of the applied literature}

Although geopolitical phenomenology has an extremely old manifestation and can be identified until the earliest dawn of human civilization, the idea of risk and, in particular, geopolitical risk is more recent, being introduced, in commercial contracts of the fourteenth century, which regulated the transport of goods by sea in the event of "a possible danger" (Franklin, 2001). It is not clear whether the potential danger was connected to a storm that could have overturned the ship or a pirates attack, however it is certain that the event probability was known and, consequently, assumed, and secured.

With regards to the emergence of current geopolitical risks, most reports from major transnational companies, agencies, international bodies in recent years, record this fact (Zurich Insurance Group, 2018; World Economic Forum, 2018; Stratfor, 2017 etc.) a Gallup poll (2017), pointing out that $75 \%$ of US investors are "worried and very worried" about the impact of world military and diplomatic conflicts on the US investment climate in 2018.

Moreover, Carney (2016) places geopolitical risks above economic and political ones, and Anderson (2017) interprets the increase of new geopolitical risks as causes by the emergence of state and non-state actors seeking to establish their identity in the new international order.

The difficulty of identifying, classifying and managing geopolitical risks was also highlighted by the business environment, according to Willis Towers Watson and Oxford Analytica (2017), while the academic environment is trying to make light in an increasingly less predictable global stage: Pardee Center for International Futures at Denver University (2017) published a report analysing a series of present geopolitical risks.

The terminology associated with geopolitical risks has also enriched the literature of recent years through various studies and reports, such as Caldara and Jacobiello, 2018; Zurich Insurance Group, 2018; WEF, 2018; Eurasia Group, 2018; AON, 2017; Andersen, 2017; Bohl, et al., 2017; Carney, 2016; Muzindutsi and Manaliyo, 2016; WEF, 2015 et al. Attempts to define the geopolitical risk were successfully materialised by: Caldara and Jacobiello, 2018; Sunshine Profits, 2018; Rabobank, 2017; Pardee Center for International Futures, 2017; Bohl et al., 2017. 
One of the main debates on geopolitical risks developed in the literature so far refers to their globalization trend and their interconnection with other types of risks, analysed by the WEF (2018).

However, their analysis as individual factors is also important, various entities and academic environment affiliated authors developing their own methodologies and indicators of geopolitical risk measurement. To this end, Caldara and Jacobiello (2018), economists at the Federal Reserve (US), have created a geopolitical risk index (GPR index) that allows realtime measurement of this type of risk such as it is reflected by the mass media, public opinion, global investors and political decision-makers. Also, the Institute for Economics and Peace, founded in 2007 by IT entrepreneur Steve Killelea, has created a global index of terrorism (GTI) and a series of peace indices, including the global peace index (GPI).

As far as the impact of geopolitical risk on tourism is concerned, Tekin (2015) shows that there is literature that has tracked the impact of political instability and economic crises on tourism, but these risks have been treated separately without interrelationship between them. Of the local / regional studies, we only mention Haddad et al. (2015) on the impact of terrorist attacks on the number of tourists visiting Egypt and the one of Luedi (2016), which looks at the case of travel agencies controlled by the Chinese government and their impact on the tourist flow leaving China. In the same context, Webster and Ivanov (2015) identified a number of geopolitical factors with a major impact on the reconfiguration of future tourism flows at a global scale.

The perception of the tourist consumer on geopolitical risks was also reached, as evidenced by the study of Morakabati, Fletcher and Beavis (2017).

\section{Methodology}

This research was based, first of all, on extensive analysis of the literature in the field, in order to understand the phenomenology related to the "geopolitical risk" and the way it is received, approached and understood. In this respect, the reports run by several institutions, agencies, transnational companies have served this study with results that revealed, on one hand, the emerging trends of geopolitical risks at present and in the near future, and on the other hand, the business environment's mechanism of perceiving this new type of risk, as one that can be measured and secured in the context of its globalization.

In terms of quantitative analyses, a number of statistical databases allowed tracking of the phenomenon both in historical time (such as the Geopolitical Risk Index, calculated by Caldara and Jacobiello, 2018), as well as spatial distribution (the global index of terrorism, calculated by the Institute for Economics \& Peace, 2017). The above mentioned indices, as well as those of international tourists and tourism incomes, have been harmonized by the relationship $\mathrm{x}=(\mathrm{x}$ - $\left.\operatorname{Min}_{(\mathrm{x})}\right) /\left(\operatorname{Max}_{(\mathrm{x})}-\operatorname{Min}_{(\mathrm{x})}\right)$. Also, the $R^{2}$ coefficient of determination was calculated, in order to find out the percentage of the variation in tourism indices (international tourists and tourism income) depending on the variation of the terrorism index. 


\section{Findings and Debates}

\subsection{Brief history of the geopolitical risk}

Although manifestation of power enhanced by geographic factors is as old as humanity itself and, even when means to define certain phenomenologies have been individualized, particularly starting with the mid- $19^{\text {th }}$ century, geopolitics has never been treated as risk (in the economic meaning of the term) and, at least in reference to tourism, such association was bizarre at the least: conflicts/wars and traveling for pleasure had nothing to do with each other.

It has been therefore unanimously accepted that "the era of geopolitical risks" has been opened with the event that remained in the history as the " $9 / 11$ ", respectively the terrorist attack on World Trade Center of New York, in year 2001. Terrorism was no longer local, but it became global. For example, a survey made almost two decades later revealed that $75 \%$ of the American investors are "very or somewhat worried" about the impact of military and diplomatic conflicts around the world on the investment climate in the USA, at the level of year 2018 (Gallup, 2017; see also Caldara and Iacoviello, 2018, p. 2). Moreover, Carney (2016, p. 3) ranks geopolitical risks ahead of economic and political risks, defining the three types of risks as an "uncertainty trinity", and showing that their incidence doubled in the period from 2001 to 2015 as compared to the period from 1985 to 2001 (see also Caldara and Iacoviello, 2018, p. 35).

Interesting is the fact that the phrase "geopolitical risks" has been accepted as such and it as not interpreted or mistaken for "political risks"; moreover, it was clearly differentiated from it.

A clear distinction between the two categories of risks was made also in a different report, Willis Towers Watson and Oxford Analytica (2017, p.3) invoking, however, also the difficulty in classifying the current geopolitical risks, considering that transparency and predictability of policies in Europe and USA come to an end: "Political risk in the US and Europe has been a big surprise and, in many ways, we were not prepared for it". Therefore, although the abovementioned report made clear terminological distinction between "geopolitical risks" and "political risks", it includes the latter in the category of the former, without erring too much, considering that it involves great powers/superpowers with special impact on regional and global stability.

Other reports of various agencies, think-tanks, international organizations explicitly specifying geopolitical risks may be added to all these. For example, the World Economic Forum (2018) stipulates: "The escalation of geopolitical risks was one of the most pronounced trends in 2017.” (WEF, 2018, p. 10)

Likewise, in its annual forecast, Stratfor, a geopolitical intelligence platform, (also called "the Shadow CIA") warns from the very first pages that "geopolitics is back with a vengeance" (Stratfor, 2017, p. 4), the phrase "vengeance" apparently being one of the favorites, if we were to consider also the paper of its geopolitical analyst, Robert Kaplan, of 2012 (translated also into Romanian in 2014), namely "The Revenge of Geography". For that matter, even H.R. McMaster, national security adviser of the United States in 2017 under Trump administration, similarly stated: "Geopolitics are back, and back with a vengeance, after this holiday from history we took in the so-called post-Cold War period." (Stratfor, 2017, p. 5) 
Anderson (2017) puts the catalyzing effect on geopolitical risks on account of the rise of state and non-state actors looking to establish their identity in the emerging new world order, Dominique Moisi (2017) stating that: "For the first time since the $18^{\text {th }}$ century, the West is no longer the only center of the world, the West has lost its monopoly of models. We see something like the torch of history passing from West to East.” (Anderson, 2017).

As regards the general landscape of the emerging new world order, it has been defined by the World Economic Forum, at the beginning of this year as follows: "The world has moved into a new and unsettling geopolitical phase. It is not just multipolar, but multiconceptual" (WEF, 2018, p. 37), the report putting the upsurge of geopolitical risks on account of the fact that "multilateral rules-based approaches have been fraying" (WEF, 2018, p. 10), even citing the plead to unilateralism of Donald Trump, in his electoral campaign of 2017 ("America first"), unilateralism that became a strategy adopted by many great powers, becoming a "sand shifts" for small countries in the geopolitical landscape.

The general overall landscape is taken into consideration also by the business environment, in its attempt to operationalize geopolitical risk (identify measure, manage, forecast), the report of Zurich Insurance Group company for 2018, stating: "Geopolitical volatility has become a key driver of uncertainty, and will remain one over the next few years. Geopolitical risks are interrelated, so they need to be looked at holistically in the context of other risks. Understanding the connections between different kinds of risks is a vital step in risk mitigation."

The idea of interconnectivity of geopolitical risks with other types of risks is highlighted also by the World Economic Forum (2018), which publishes a map of the interrelationship between five types of risks, as trend for the current year: 1. geopolitical risks (collapsed states or crises, interstate conflicts, failure of global, regional or national governance, terrorist attacks), 2. economic risks (failure of critical infrastructure, fiscal crisis, deflation, unmanageable inflation, illicit trade, failure of financial mechanisms or institutions, asset bubbles, unemployment, etc.), 3. environmental risks (environmental crises, natural disasters, climate change, biodiversity loss and ecosystem collapse), 4. technological risk (cyberattacks), 5. societal risks (migration, social instability, water crises, food crises, spread of infectious diseases, failure of urban planning).

Particularly interesting is also the evolution of the risk landscape in the past decade, the same report (WEF, 2018), showing that in 2008 to 2010 the likelihood of occurrence of geopolitical and economic risks was dominant, but after that period, the environmental risks became prominent, next to geopolitical risks (the latter peaking in 2015). However, in terms of impact economic risks conceded the foreground to geopolitical risk in the period from 2015 to 2018, and in the last two years of the period subject to analysis, respectively 2017 and 2018, the impact of weapons of mass destruction occupied the first place and natural disasters occupied the following three places.

All these recent reports do nothing but emphasize the accentuated dynamics of a world in motion. Particularly important is the considerable decrease of predictability of a world based on rules, with the specification that this trends manifests also where no one expected: in the West (Brexit, the uprise of radical platforms in Europe, Donald Trump's wining the elections in the USA, are only several factors).

Globalization based on non-state vectors has allowed for the come back of state-based geopolitics (Donald Trump, 2017: "Make America great again, after decades of being taken 
advantage of"; Emmanuel Macron, 2017: "I would be a $<<$ Jupiterian $>>$ president", after François Hollande, a "normal" president, Jupiter being the Roman equivalent of Zeus in Greek mythology; Xi Jinping, 2017: "great rejuvenation of the Chinese nation, after a century of humiliation"; to all these, the nuclear militarism of Kim Jong-um, the nationalism of the Japanese Prime-Minister Shinzo Abe, Putin "the bull", "Erdogan, the sultan" etc.) may be added.

The trends for 2018 and the years to come show the same increased preeminence of geopolitical risks, $93 \%$ of respondents to a questionnaire on this matter indicating the friction between great powers as a source, $80 \%$ expressing concern about the probability of escalation of military conflicts (WEF, 2018, p. 10). Willis Towers Watson and Oxford Analytica (2017) include the following in the top of current geopolitical threats: international sanctions on Russia, protectionism, populism, ends of globalization consensus, US policy volatility, Mideast regional tensions, regime stability in Saudi Arabia, regime stability in Russia, disruptions from rising China, North-Korean tensions.

\subsection{Terminology}

Although most common dictionaries define risk in the meaning of peril, possible/probable hazard, the Greek and Latin forms of the term reveal additional meanings, as follows: the

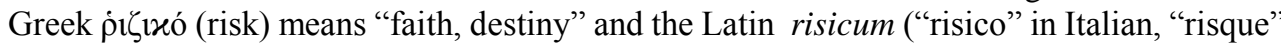
in French and "risk" in English), something possible/probable (which will happen, but without knowing when).

Interesting is the Italian meaning of the verb "risicare" = to dare, inferring the idea that risk becomes a choice (not a given).

Alexander Lombard's (1307) "Treatise on Usury", "treats risk and doubt as synonymous, uses the terms probable and likely, and treats more probable as meaning <<which happens more frequently $>>$ (apud Franklin, 2001, p. 271). Franklin (2001, pp. 273-274) also considered that: "Ancient Roman law does not have an insurance contract (...), but there is the idea of <<uncertain peril >> of the voyage (...), thus they come close to the essential idea of insurance. (...) A contract from 1319-20 comes very close to true insurance by this route. A large Florentine firm buys Flemish and French cloth at the Champagne fairs and delivers it to Pisa, at the risk of the sellers but at the buyer's expense. There is an extra charge of $8.75 \%$, called rischio, for assuming this risk [voyage by sea]".

All the above reveal the emergence of the term risk in general, and its economic component - risk insurance.

As regards geopolitical risk, a myriad of associated phrases and terms have accompanied the individualization and definition thereof, among which: "geopolitical uncertainty" (Carney, 2016, p. 2); "geopolitical threat", with a more extended notional family: "war threat", "nuclear threat", "terrorist threat", "war acts", "terrorist acts" in Caldara and Iacoviello (2018, p. 31); "geopolitical volatility" in Zurich Insurance Group (2018), WEF (2018); "geopolitical turmoil" in Andersen (2017); "geopolitical stress"; "geopolitical disruptions"; "geopolitical shifts" in Bohl et al. (2017, p. 7); "geopolitical recession" and "geopolitical depression"; "geopolitical accident" in Eurasia Group (2018, p. 3, 7); "[geo]political unrest" in Muzindutsi and Manaliyo (2016, p. 173); "geopolitical tensions" in WEF (2015) and AON (2017); "geopolitical sands shift" (WEF, 2018, p. 7); "geopolitical strains" (WEF, 2018, p. 10) etc. 


\subsection{Definition}

Under Caldara and Iacoviello, Federal Reserve (USA) defines geopolitical risk as "the risk associated with wars, terrorist acts, and tensions between states that affect the normal and peaceful course of international relations" (2018, p. 6). The two authors notice the wide semantic field in which the term "geopolitics" has been used in the past years, which generated a certain amount of confusion in delimiting geopolitical risks; however, we cannot overlook the fact that a series of studies illogically and unjustifiably used this phrase only to be "à la mode", in accordance with the trends of newspaper articles, television shows and, why not, academic studies, the two authors showing that the term geopolitics "covers a diverse set of events with a wide range of causes and consequences, from terrorist attacks to climate change, from Brexit to the Global Financial Crisis" (Caldara and Iacoviello, 2018, p. $6)$.

That is why the two authors exclude from the definition given to geopolitical risks the phenomenology associated with "major economic crises" (international financial crisis, debt crisis in Euro Area), "major democratic political events" (Brexit), others such as climate changes, movements concerning certain civil rights, etc.

The definitions used by various consultancy companies or private companies in their own research particularize geopolitical risk as "the risk of one country's foreign policy influencing or upsetting domestic political and social policy in another country or region" (Sunshine Profits, 2018) or "instances of conflict between countries or international organizations that have a disruptive economic impact on at least a continental scale" (Rabobank, 2017).

Evidently, attempts to define and conceptualize geopolitical risks have been made also in the university and academic environment. For example, Pardee Center for International Futures (2017) defines it as "potential for disruption of political-economic trends conducive to human wellbeing", and Bohl et al. (2017, pp. 7-8) concludes that "geopolitical risk emanates from three interconnected systems, respectively the interrelationship of three other types of risks, specifically: political, economic, and natural.", where political risk derives from the interaction of actors engaged in the race for power, economic risk from the dynamics of market interactions (for example, the international financial crisis of 2008), and the natural risk derives from natural hazards (desertification, climate change etc.).

In what it concerns us, we define geopolitical risk as any type of risk derived from geopolitical factors, affecting social and economic activities and behaviors, where by geopolitical factor we understand power manifestation of state or non-state actors, conditioned (maximized) by geographic factors: tensions, crises, conflicts, states of conflict, international wars, annexation of certain territories (Crimea, 2014), frozen, asymmetric, hybrid conflicts, international terrorism (ISIS) and others.

Naturally, in addition to these typical geopolitical risks, other pseudo-geopolitical risks can occur, respectively that category of risks that, although do not initially derive from geopolitical factors, but from factors of different nature (natural, economic, social etc.) may cause uncertainty and have geopolitical effects. For example: political events (coup d'etat, East-European revolutions, colour revolutions, Arab Spring, exists such as Brexit, upraise of radical or radicalized, extremist platforms), economic risks (economic, financial crises, economic conflicts - "gas war", "gas pipe war") etc., natural risks (climate warming and melting of the Arctic ice, having as effect the non-differentiation of territorial waters off the 
North-Canadian archipelagos by the USA, disputing transport routes in the Arctic Ocean, increase of desertification in Africa with implication in catalysing water and land-related conflicts etc.).

\subsection{The impact of geopolitical risks on tourism}

Geopolitical risk entails, first of all, manifestation of hard power, irrespective of its form, while the sine-qua-non condition for the existence of tourism as a phenomenon is the guarantee for freedom, liberty, which, in its turn is conditioned by power games (Figure no. $1)$.

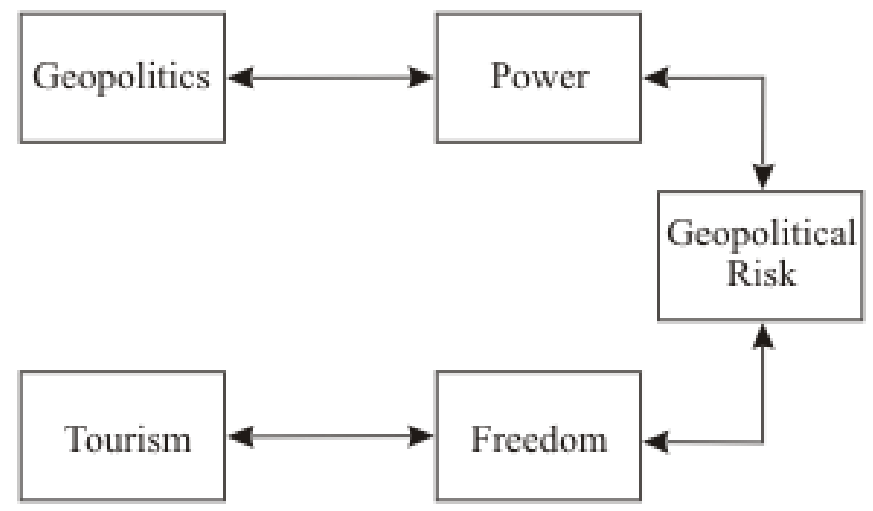

Figure no. 1: The theoretical scheme displaying the relationship between geopolitics and tourism

The impact of geopolitical risks on tourism as a phenomenon is wide, and it may be observed in all quantitative and qualitative dimensions of this social and economic activity (Figure 2), from the actual destruction of the tourism resource up to alteration of the infrastructure and change of the social and spatial behaviour of tourist flows.

As early as 2015, Webster and Ivanov identified a series of geopolitical factors with major impact on reconfiguration of future tourist flows, amongst which: the decline of the USA as superpower and emergence of China in this role, with impact on the global landscape where tourism and hospitality industry should function, in general; emergence of BRIC[S] states Brazil, Russia, India, China, [South Africa] and PINE state - Philippines, Indonesia, Nigeria, Ethiopia, the two block concentrating together half of the Globe's population (over 3.5 billion inhabitants), impacting the development of tourism both in capacity of countries generating tourist flows and as destination countries, the future of English language as standardized language in tourism and the gastronomic culture; political instability and territorial fragmentation (secessionist movements and emergence of new states) negatively impacting the security climate and tourism activity i.a.

Another recent study (Morakabati, Fletcher and Beavis, 2017) mapped the perception of tourists from nine tourist flow-generating countries (Great Britain, USA, China, Japan, South Africa, Germany, France, Russia, India) on destination countries, from the perspective of geopolitical risks, also revealing a top of "fear to travel" regions, amongst the first being: Iran (over 40\%), Israel and Turkey (over 25\%), 97\% of over 6,000 interviewed individuals 
being concerned, first of all, with their personal safety when selecting a vacation destination, this personal safety being closely related to the acute perception of the terrorist phenomenon.

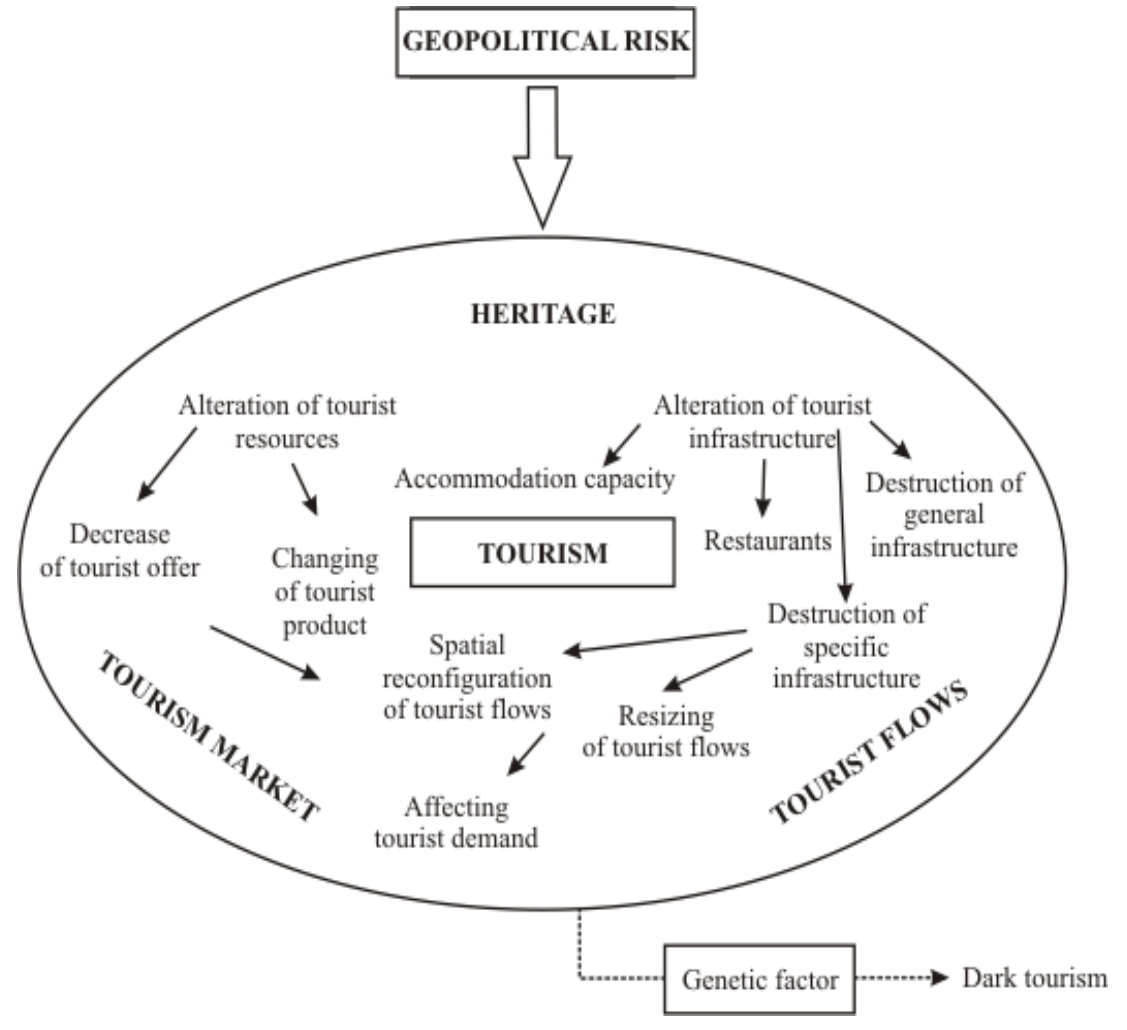

Figure no. 2: The theoretical scheme of the impact of geopolitical risks on tourism

The impact on tourist heritage. A direct effect of geopolitical risks is the alteration of the global tourist heritage, some tourism resources being destroyed in wars or terrorist attacks (Table no. 1).

Table no. 1: The impact of geopolitical risks on the cultural heritage

\begin{tabular}{|c|l|l|l|}
\hline Year & $\begin{array}{l}\text { Country } \\
\text { (Location) }\end{array}$ & $\begin{array}{l}\text { Destroyed tourist landmarks (listed } \\
\text { on the UNESCO World Heritage) }\end{array}$ & Geopolitical event \\
\hline 2001 & $\begin{array}{l}\text { Afghanistan } \\
\text { (Bamiyan) }\end{array}$ & $\begin{array}{l}\text { Two monumental statues of Buda } \\
\text { (53 m and 35 m high, 1 500 years old) }\end{array}$ & $\begin{array}{l}\text { Taliban control } \\
\text { (explosion) }\end{array}$ \\
\hline 2003 & Iraq & Robbery of numerous archaeological sites & US military invasion \\
\hline 2005 & $\begin{array}{l}\text { Armenia } \\
\text { (Julfa) }\end{array}$ & $\begin{array}{l}\text { The medieval Armenian cemetery in } \\
\text { Nahicevan exclava (on the territory of } \\
\text { Azerbaijan), with unique tombstones } \\
\text { (khachkars) }\end{array}$ & Azeri-Armenian conflict \\
\hline 2011 & $\begin{array}{l}\text { Bahrain } \\
\text { (A'ali) }\end{array}$ & $\begin{array}{l}\text { Shiite Mosque Amir Mohammed Barbag } \\
\text { (400 years old) }\end{array}$ & $\begin{array}{l}\text { The Arab Spring } \\
\text { (governmental reprisals) }\end{array}$ \\
\hline
\end{tabular}




\begin{tabular}{|c|c|c|c|}
\hline \multicolumn{4}{|c|}{ The Impact of Geopolitical Risks on Tourism } \\
\hline Year & $\begin{array}{c}\text { Country } \\
\text { (Location) }\end{array}$ & $\begin{array}{l}\text { Destroyed tourist landmarks (listed } \\
\text { on the UNESCO World Heritage) }\end{array}$ & Geopolitical event \\
\hline $\begin{array}{l}2013 \\
2015\end{array}$ & Libya & Ancient site of Cyrene & $\begin{array}{l}\text { Arab spring (civil war); } \\
\text { ISIS attack }\end{array}$ \\
\hline $\begin{array}{l}2014- \\
2015\end{array}$ & $\begin{array}{l}\text { Iraq } \\
\text { (Mosul } \\
\text { area) }\end{array}$ & $\begin{array}{l}\text { The ancient archaeological sites of } \\
\text { Nimrud, Hatra; akkadian artefacts; Bash } \\
\text { Tapia medieval castle; The ruins of } \\
\text { Christian Dairy Mar Elia; Mosul Museum } \\
\text { artifacts }\end{array}$ & $\begin{array}{l}\text { Northern Iraq's } \\
\text { occupation by the Islamic } \\
\text { State (ISIS) }\end{array}$ \\
\hline 2014 & $\begin{array}{l}\text { Egypt } \\
\text { (Cairo) }\end{array}$ & Museum of Islamic Art & Terrorist attack \\
\hline $\begin{array}{l}2015- \\
2018\end{array}$ & Syria & $\begin{array}{l}\text { Palmyra; Aleppo Historic Center ( } 30 \%) \text {; } \\
\text { Historic Center of Damascus; Bosra; } \\
\text { Temple Ain Dara of Afrin; So mamny } \\
\text { other inestimable artefacts with an impact } \\
\text { yet unknown }\end{array}$ & $\begin{array}{l}\text { Blown up by the Islamic } \\
\text { State (ISIS) } \\
\text { Civil War in Syria } \\
\text { Turkish incursions in } \\
\text { northern Syria }\end{array}$ \\
\hline
\end{tabular}

In extreme cases, such as that of Syria, the erosion of the global cultural and tourist heritage of inestimable value was doubled by total destruction of the tourism infrastructure and a tourist flow reduced to nil. For example, in 1998 Syria had 1.3 million international tourists, 5.4 million in $2008,8.5$ million in 2010, after which the collapse began with the "Arab Spring" in 2012 and the statistics did not record tourist flows anymore (cf. World Bank, 2018).

Impact on tourist flows. The most sensitive barometer of the relationship between power games and tourism is the tourist flow, which is redimensioned and reconfigured depending on these conditionings. In four instances analyzed (Figure no. 3) - Turkey, Ukraine, Egypt, France - representative countries for receiving significant flows of international tourists, but strongly affected by power games in the past years, there is a direct relationship between the number of foreign tourists received, the revenue obtained from tourism and the geopolitical risk index and that of terrorism.

Terrorist attacks in Sharm el Sheikh (2005) and on Dahab resort in Sinai Peninsula (2006) lead to a reduction of the number of foreign tourists by $8 \%$, in 2006 , despite the ascending trend.
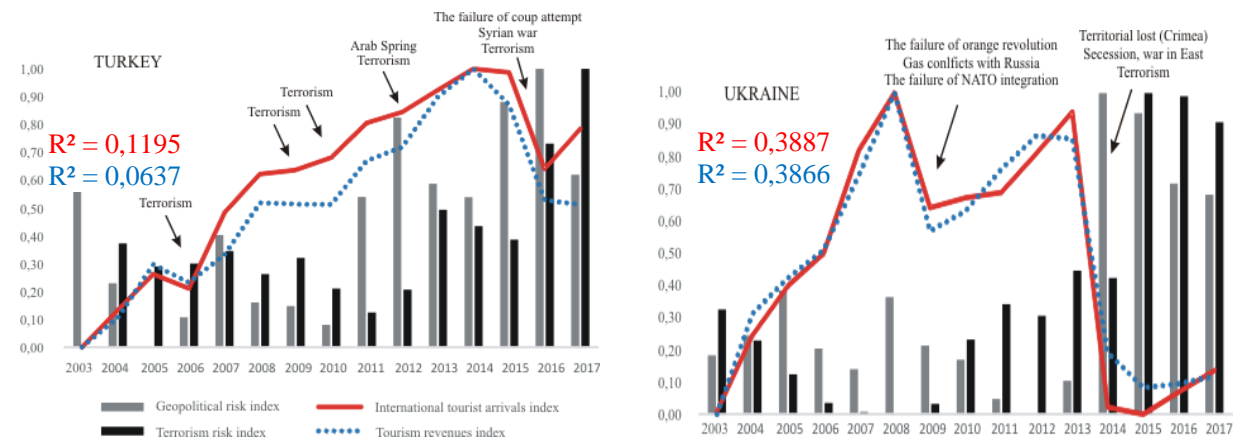

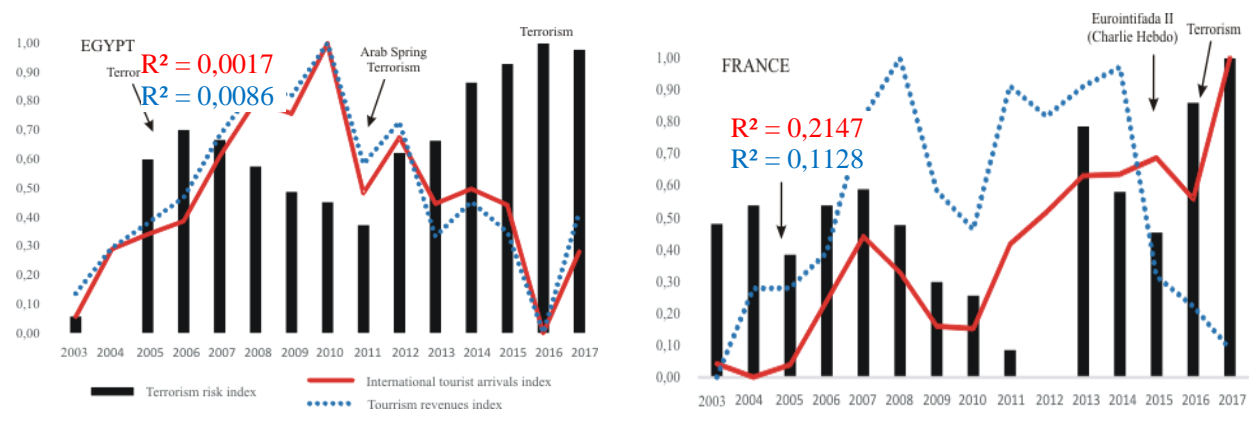

Figure no. 3: The impact of geopolitical risks on tourist flows

The collapse enhanced starting from year 2011, when the "Arab Spring" phenomenon catalyzed a series of terrorist attacks, the context being finally shaped by the instability phenomenon affecting the vicinities (Syria and ISIS); from over 14 million foreign tourists, in 2010, Egypt recorded only little over 5 million in 2016.

Likewise, Turkey, a country that experienced a genuine tourism "boom" in the past decade and economic growth of over $10 \%$ in mid economic crisis affecting Europe, was also faced with the evil effects of the manifestation of power starting with 2014, at the same time with the evolution of the theatre of operations in Syria, the domestic turmoil, the endless series of terrorist attacks, the disputes between Vladimir Putin and Recept Erdoğan, which led to a true "tourism crisis in Antalya", after the Turkish army gunned down a Russian military plane in Syria, have all lead to the decrease of the number of tourists, and that of the revenue from tourism accordingly: from approximately 40 million foreign tourists and 39 billion dollars (2014) to 30 million tourists, respectively 27 billion dollars, in 2016.

Similarly, after the repeated attacks in the French capital, Paris lost in $2016,5 \%$ of its tourists (over 1.5 million visitors, according to France24, 2017), the terrorist phenomenon being also present (March 2018) and the security climate being quite uncomfortable for tourists (additional security filters in shops, tourist objectives, on the streets, in railway stations, not to mention the usual ones in railway stations) associated with delays, etc. Similar situations were in London, Brussels, Barcelona and others.

The secessionist effects (Catalonia 2017, Lugansk and Donbass 2014-2018) have no lesser impact on tourism, on the contrary, from 25 million tourists in 2008 , Ukraine accounted only 12 million in 2015 and examples can continue.

Despite this intuitive influence of the geopolitical risk on tourism activity and phenomenology, as well as by the quantitative analyses show (Figure 3 ), the $\mathrm{R}^{2}$ coefficient of determination calculated in the four case studies (Figure 3 ) indicates that only very small percentages of the variation of international tourists and tourism incomes indices can be explained by the variation of the terrorism index. For example, Ukraine has the highest values of $\mathrm{R}^{2}$ : only $38 \%$ of the variation of tourism indices is determined by the variation of the terrorism index.

The explanations are multiple: from the small series of statistical data (the intensification of the terrorist phenomenon on a global scale only in recent years) and up to the volatility of tourist activity in certain types of economy. 
Evidently, the impact of tourist flows is not limited to decreased tourist flows or their reconfigured geography, but go so far as to alter the social and spatial behaviour of the tourist, the attitude towards space (which can go from topophilia to topophobia).

Moreover, the manifestation of geopolitical risks can generate a specific type of tourism, such as dark tourism, the tourist resources consisting, in this case, of buildings affected by war (such as, for example, those affected by the fights in 1992-1995, in former Yugoslavia).

\section{Conclusions}

Following the analysis of the impact that geopolitical risks have on tourism, the conclusions bellow resulted.

The geopolitical risk started to be approached by specialized literature both as phrase, and as theoretical construct. The evolution of geopolitics as field of studies has been known since it has been individualized, at the end of the $19^{\text {th }}$ century and up to the present time, and likewise its long period of "purification", including a terminological and academic phase, in the second half of the $20^{\text {th }}$ century. The evolution of the post Cold War reality and particularly the return of Russia as superpower on the international stage, corroborated with the problems facing the West and emergence of new power poles, amplified the return of geopolitics, with its array of methods and tools for better understanding the world. In this context, the applied market research (reports of various companies and international bodies), more advanced than that of universities, revealed two essential aspects: 1. clear differentiation of geopolitical and political risks and 2. the acceptance of the phrase "geopolitical risk", with the corresponding terminology, definition, components and mechanisms.

All this applied research, such as that of large transnational insurance companies, emphasizes the emergence of geopolitical risks in the present and near future. Moreover, this type of risk is no longer perceived as isolated, or treated as such, but globally. This amplitude of the phenomenon has also imprinted the forceful come-back of the "geo-" prefix.

Globalization of the "geopolitical world" has thus become an underlying coordinate in analyses attempting to offer a minimum forecast to the investment and business environment, the economic rationale and classic economic risks fading into the background. The surprise concerning the general landscape came, this time, from the West, weak and affected by crises, some of which systemic, of liberal tendency and (ultra)nationalist centrifugation.

In this context, a series of methodologies and geopolitical risk measurement indexes, such as geopolitical risk index or global terrorism index, have been developed in the attempt to quantify in terms of numbers how safe is a country from the point of view of the geopolitical risk.

The impact of geopolitical risks on tourism is visible in several areas, such as: effects on the tourist heritage, which may go so far as the disappearance of resources or objectives from the world heritage, some of which on the UNESCO list (more recently, the case of antic sits in Syria); redimensioning of tourist flows and their geographic reconfiguration (diplomatic crises, terrorist attacks, escalating conflicts, territorial secessions, and others having these effects); emergence of a specific form of tourism, respectively the dark tourism which capitalize on artefacts of war. 


\section{References}

AON, 2017. 2017 Risk Maps. Aon's guide to Political Risk, Terrorism \& Political Violence. [pdf] AON. Available at: <www.aon.com/2017-political-risk-terrorism-and-politicalviolence-maps/pdfs/2017-Aon-Risk-Maps-Report.pdf> [Accessed 25 February 2018].

Anderson, D., 2017. Risks multiply in a divided world, [online] Available at: <www.zurich.com/en/knowledge/articles/2017/12/risks-multiply-in-a-divided-world> [Accessed 24 February 2018].

Bohl, D.K., et al., 2017. Understanding and Forecasting Geopolitical Risks and Benefits, [online] Available at: <pardee.du.edu/understanding-and-forecasting-geopolitical-risksand-benefits> [Accessed 24 February 2018].

Carney, M., 2016. Uncertainty, the economy and policy. [pdf] London: Bank of England. Available at: <www.bis.org/review/r160704c.pdf> [Accessed 24 February 2018].

Caldara, D. and Iacoviello, M., 2018. Measuring Geopolitical Risk. [pdf] Boston: Division of International Finance. Available at: <www2.bc.edu/matteo-iacoviello/ gpr_files/GPR_PAPER.pdf> [Accessed 24 February 2018].

Eurasia Group, 2018. Top risks 2018. [pdf] New York: Eurasia Group. Available at: <https://www.eurasiagroup.net/files/upload/Top_Risks_2018_Report.pdf> [Accessed 24 February 2018].

France24, 2017. 1.5 million fewer tourists visited Paris in 2016, [online] Available at: <www.france24.com/en/20170221-paris-tourism-terror-attacks-air-france-boost-pilotshsbc-results> [Accessed 25 February 2018].

Franklin, J., 2001. The Science of Conjecture. Evidence and Probability Before Pascal. Baltimore: Johns Hopkins University Press.

Fukuyama, F., 1997. Sfârșitul istoriei și ultimul om. București: Paideia.

Gallup, 2017. Geopolitical Risks Greater Threat to Investments Than the Economy. New York: Wells Fargo/Gallup. Available at: <www.businesswire.com/news/home/ 20170613005348/en/> [Accessed 24 February 2018].

Haddad, C., Nasr, A., Ghida, E. and Ibrahim, H.A., 2015. How to re-emerge as a tourism destination after a period of political instability. In: World Economic Forum, 2015. The Travel \& Tourism Competitiveness Report 2015. Geneva: World Economic Forum. Ch.1.3, pp. 53-57.

Institute for Economics and Peace, 2017. Global terrorism index, [online] Available at: <globalterrorismindex.org/> [Accessed 24 March 2018].

Luedi, J., 2016. Political risks rock China's tourism industry, [online] Available at: <globalriskinsights.com/2016/10/political-risks-rock-chinas-tourism-sector/> [Accessed 25 February 2018].

Middeldorp, M., Groenewegen, J. and de Vreede, I., 2017. Outlook 2018: The economic impact of geopolitical risks and events on the Dutch economy. Economic Quarterly Report, [online] Available at: <economics.rabobank.com/publications/2017/december/ outlook-2018-the-economic-impact-of-geopolitical-risks/> [Accessed 24 February 2018].

Morakabati, Y., Fletcher, J. and Beavis, J., 2017. State of play: the impact of geopolitical events on international tourism in 2017. [pdf] Available at: <www.itb- 
berlin.de/media/itb/itb_dl_en/itb_itb_berlin_en/itb_itb_academy_en/Travelzoo_Studie_ ITB_2017.pdf > [Accessed 25 February 2018].

Munoz, J.M., 2013. Handbook on the Geopolitics of Business. Cheltenham: Edward Elgar Publishing.

Muzindutsi, P.F., Manaliyo, J.C., 2016. Effect of Political Risk Shocks on Tourism Revenue in South Africa: Time Series Analysis. International Journal of Business and management Studies, 8(2), pp. 169-186.

Neacșu, M.C., 2016. Geoeconomic vs. Geostrategic Conflicts. Case study: Russia vs. Western World. Strategic Impact, 58(1), pp. 13-22.

Neguț, S., 2008. Geopolitica. Universul puterii. București: Meteor Press.

Negut,, S. and Neacșu, M.C., 2013. Tourism, Expression of Freedom in The Global Era. International Journal for Responsible Tourism, 2(3), pp. 45-53.

Normand, F., 2009. Les États-Unis présentent le principal risque géopolitique. Les Affaires, [online] Available at: <www.lesaffaires.com/strategie-d-entreprise/entreprendre/lesetats-unis-presentent-le-principal-risque-geopolitique/500961> [Accessed on 25 March 2018].

Stratfor, 2018. 2018 Annual Forecast. [pdf] Austin: Stratfor. Available at: $<$ www.stratfor.com/sites/default/files/Stratfor-Worldview-2018-Annual-

Forecast.pdf?utm_source=Daily+Brief\&utm_campaign $=4 \mathrm{f} 110 \mathrm{c} 91 \mathrm{e} 8$ -

EMAIL_CAMPAIGN_2018_01_12\&utm_medium=email\&utm_term=0_87179e919a4f110c91e8-53583037\&mc_cid=4f110c91e8\&mc_eid=aacaca11a6> [Accessed 24 February 2018].

Sunshine Profits, 2018. Precious metals investment terms A to Z. Geopolitics and gold. Geopolitical risk, [online] Available at: <www.sunshineprofits.com/goldsilver/dictionary/gold-geopolitical-risk/> [Accessed 24 February 2018].

Tekin, E., 2015. The Impacts of Political and Economic Uncertainties on the Tourism Industry in Turkey. Mediterranean Journal of Social Sciences, 6(2), pp. 265-272.

Webster, C. and Ivanov, S., 2015. Geopolitical drivers of future tourist flows. Journal of Tourism Futures, 1(1), pp. 58-68.

Willis Towers Watson and Oxford Analytica, 2017. How are leading companies managing today's geopolitical risks?, [online] Available at: <www.oxan.com/services/advisory/ country-risk/political-risk-management-survey/> [Accessed 25 February 2018].

World Bank, 2018. World Bank Open Data, [online] Available at: <data.worldbank.org/> [Accessed 24 March 2018].

World Economic Forum (WEF), 2018. The Global Risks Report 2018. Geneva: World Economic Forum.

World Economic Forum (WEF), 2015. The Travel \& Tourism Competitiveness Report 2015. Geneva: World Economic Forum.

World Tourism Organisation (UNWTO), 2017. Egypt: Country-specific: Basic indicators (Compendium) 2012-2016, [online] Available at: <www.e-unwto.org/doi/abs/10.5555/ unwtotfb0818010020122016201712> [Accessed 25 February 2018].

Zurich Insurance Group, 2018. Geopolitical risks, [online] Available at: <www.zurich.com/ en/knowledge/topics/geopolitical-risks> [Accessed 24 February 2018]. 